
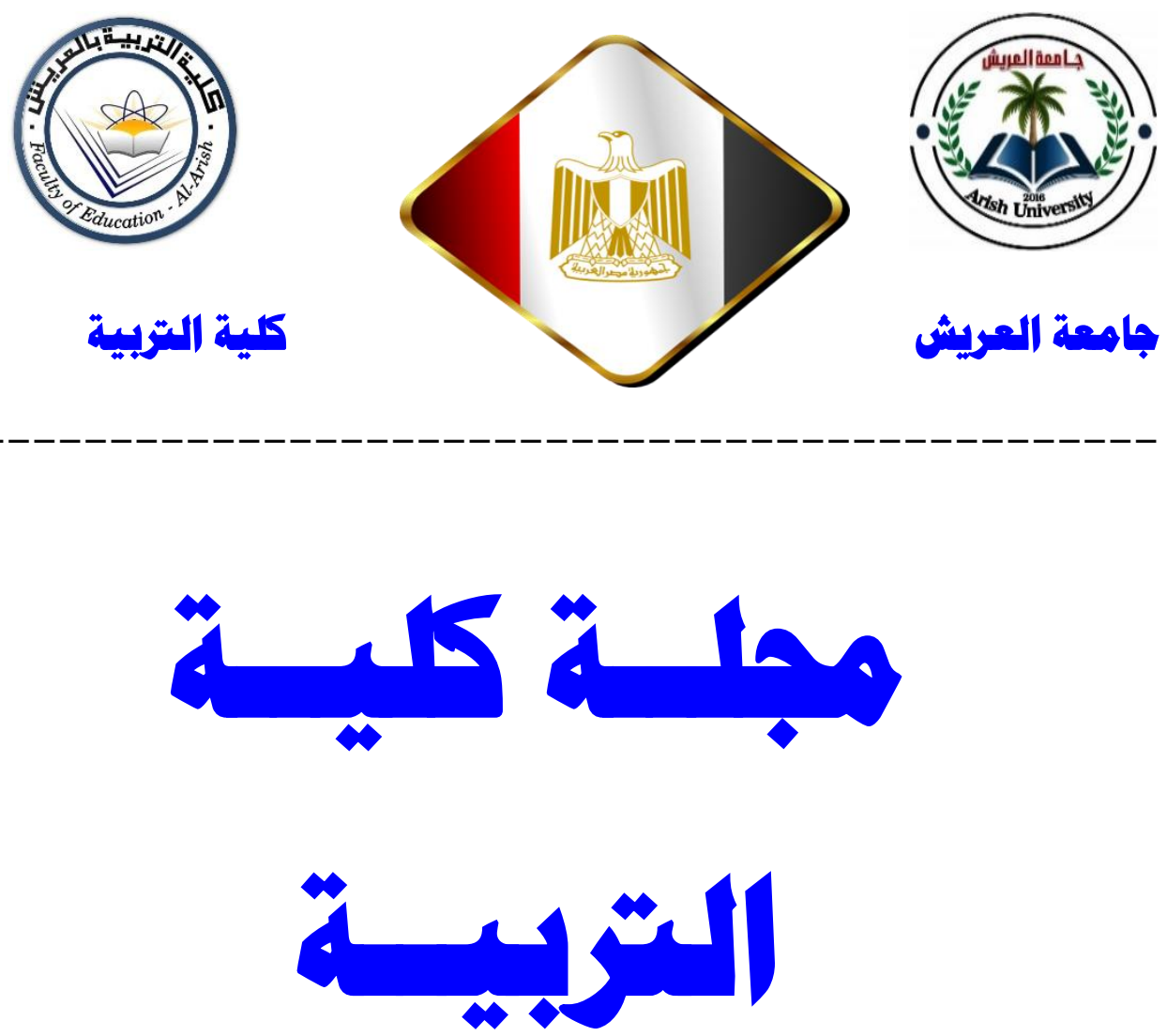

علمية محكمة ربع سنوية

(السنة السابعة - العدد السابع عشر -يناير 9 ( •؟م)

j_foea@aru.edu.eg 


\section{الإشـراف العــام}

\begin{tabular}{|c|c|}
\hline 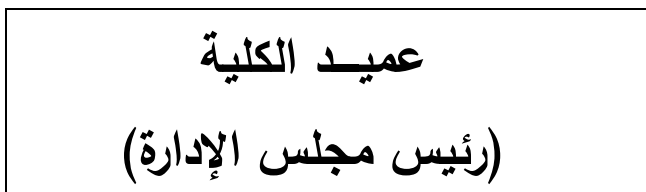 & أ.د. رفعت عمر عزوز \\
\hline وكيل الكلية للاراسات العليا والبحوث & أ.د. السيد كامل الثربيني \\
\hline
\end{tabular}

\section{هينة التمرير}

\begin{tabular}{|c|c|}
\hline رئيس التحرير & أ.د. محمد رجب فضل الله \\
\hline مدير التحرير & أ.د. أحمد عبد العظيم سالم \\
\hline عضو & د. كمال طاهر موسى \\
\hline عضو & د. أسماء حسن صبًاح \\
\hline
\end{tabular}

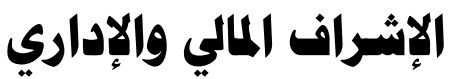

\begin{tabular}{|c|c|}
\hline المسؤول المالي & أ. محمد إبراهيم محمد عريبي \\
\hline المسؤول الإداري & محمد علي الثاعر \\
\hline
\end{tabular}




\section{قواعد النشر بهملة كلية التربية بالعربشي}

ا. تتشر المجلة البحوث والدراسات التي تتوافر فيها الأصالة والمنهجية السليمة على ألا يكون البحث المقدم للنشر قد سبق وأن نشر، أو تم تقديمه للمراجعة والنشر لدى أي جهة أخرى في نفس وقت تقديمه للمجلة. r. تُقبل الأبحاث المقدمة للنشر بإحدى اللغتين: العربية أو الإنجليزية.

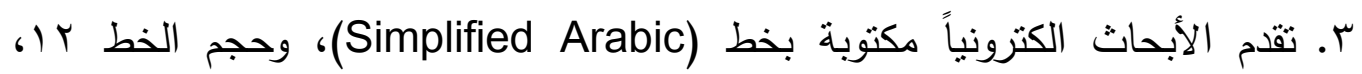
وهوامش حجم الواحد منها ه.بم، مع مراعاة أن تتسق الفقرة بالتساوي ما بين الهامش الأيسر والأيمن (Justify). وترسل إلكترونياً على شكل ملف ( Microsoft) . (Word

ع. يجب ألا يزيد عدد صفحات البحث الئحكم بما في ذلك الأشكال والرسوم والمراجع والجداول والملاحق عن (Y0) صفحة. (الزيادة بحد أقصى • (1 صفحات برسوم إضافية). ولا يزيد البحث المُستل عن ( • r صفحة ) (الزيادة بحد أقصى 0 صفحات برسوم إضافية).

ه. يقلم الباحث ملخصاً لبحثه في صفحة واحدة، تتضمن الفقرة الأولى ملخصاً باللغة

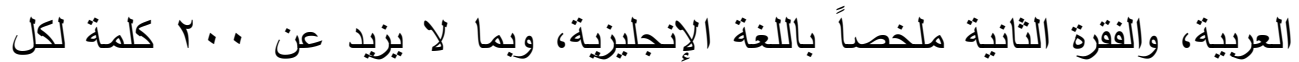

منها.

7. يكتب عنوان البحث واسم المؤلف والمؤسسة التي يعمل بها على صفحة منفصلة ثم يكتب عنوان البحث مرة أخرى على الصفحة الأولى من البحث.

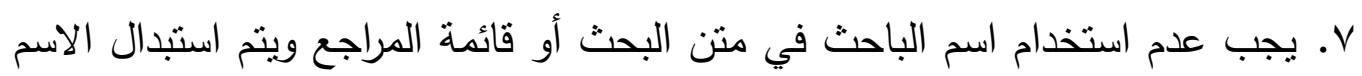
بكلمة "الباحث"، ويتم أيضاً التخلص من أية إثنارات أخرى تدل على هوية المؤلف.

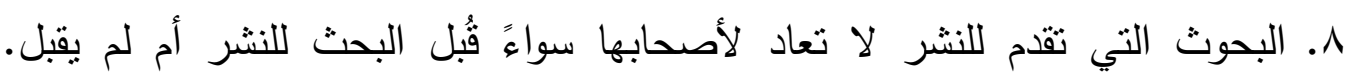
وتحتفظ هيئة التحرير بحقها في تحديد أولويات نشر البحوث. 
9. لن ينظر في البحوث التي لا تتفق مع شروط النشر في المجلة، أو تلك التي لا تشمل على ملخص البحث في أي من اللغتين، أو يزيد عدد صفحاتها عن هـ

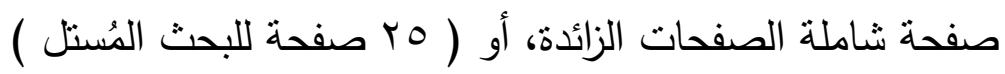
• 1. يقوم كل باحث بنسخ وتوقيع وإرفاق إقرار الموافقة على اتفاقية النشر . 11. يسهم الباحث في تكاليف نشر بحثه، ويتم تحويل التكلفة على الحساب الخاص بالمجلة. يجب إرسال صورة عن قسيمة التحويل أو دفع المبلغ، مع البحث الكترونيا. التكاليف تشمل: مكافأة التحكيم، وتكلفة الطباعة والنشر ، والحصول على نسخة من العدد، وعدد ( 0 ) مستلات من البحث المُحكم، و ( r ) من البحث المُستل. r ا. ـ يتم نشر البحوث أو رفض نشرها في المجلة بناءً على تقارير المحكمين، ولا يسترد المبلغ في حالة رفض نشر البحث من قبل المحكمين.

سا. ـ يُمنح كل باحث إفادة بقبول بحثه للنشر بعد إتمام كافة التصويبات والتعديلات المطلوبة، وسداد الرسوم المقررة.

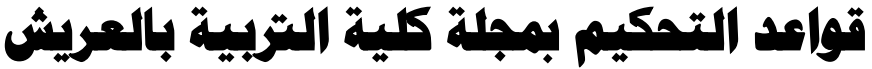

فيما يلي القواعد الأساسية لتحكيم البحوث المقدمة للنشر بمجلة كلية التربية بالعريش

\section{القم|عد عامية:}

1. مدى ارتباط موضوع البحث بمجال التربية. r. مدى مناسبة الدراسات السابقة، وإبرازها لرؤى متعددة. r. درجة وضوح أسئلة وأهداف البحث. ـ. مستوى تحديد عينة ومكان البحث.

ه. درجة إتباع البحث لمعايير التوثثق المحددة في دليل رابطة علم النفس الأمريكية، العدد السادس.

T. احتواء قائمة المراجع على جميع الدراسات المذكورة في منن البحث والعكس أيضاً

صحيح.

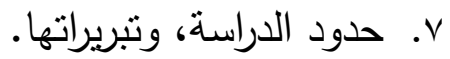


^. سلامة تقرير البحث من الأخطاء اللغوية المتعلقة بالنحو والإملاء وكذا المعنى. 9. تكامل جميع أجزاء تقرير البحث، وترابطها بشكل منطقي.

\section{قواعد المكم على منمبية البمث:}

ا. تحديد الفترة الزمنية للبحث.

r. تحديد منهجية مناسبة للبحث.

r. تبرير إجراءات للاختبار في حالة دراسة الأفراد أو الجماعات. ع. تضمين البحث إطاراً نظرياً واضحاً.

ه. توضيح الإجراءات المتعلقة بالجوانب المهنية الأخلاقية منل: الحصول على موافقة المشاركين المسبقة.

\section{قواعد تصكيم الإجزاكات:}

1. شرح وسائل جمع المعلومات بوضوح، والعمليات المتبعة فيها. r. تحديد وشرح المتغيرات المختلفة.

r. ترقيم جميع الجداول والأشكال والصور والرسوم البيانية بشكل مناسب وتبويبها والتأكد من سلامتها. ع. شرح عملية التحليل المتبعة ومبرراتها، والتأكد من اكتمالها وسلامتها.

\section{قواعد المكم على النتانئه:} 1. عرض النتائج بوضوح. r. توضيح جوانب الاختلاف في حالة تعارض نتائج البحث مع نتائج الدراسات السابقة. r. اتساق الخاتمة والتوصيات مع نتائج البحث. 


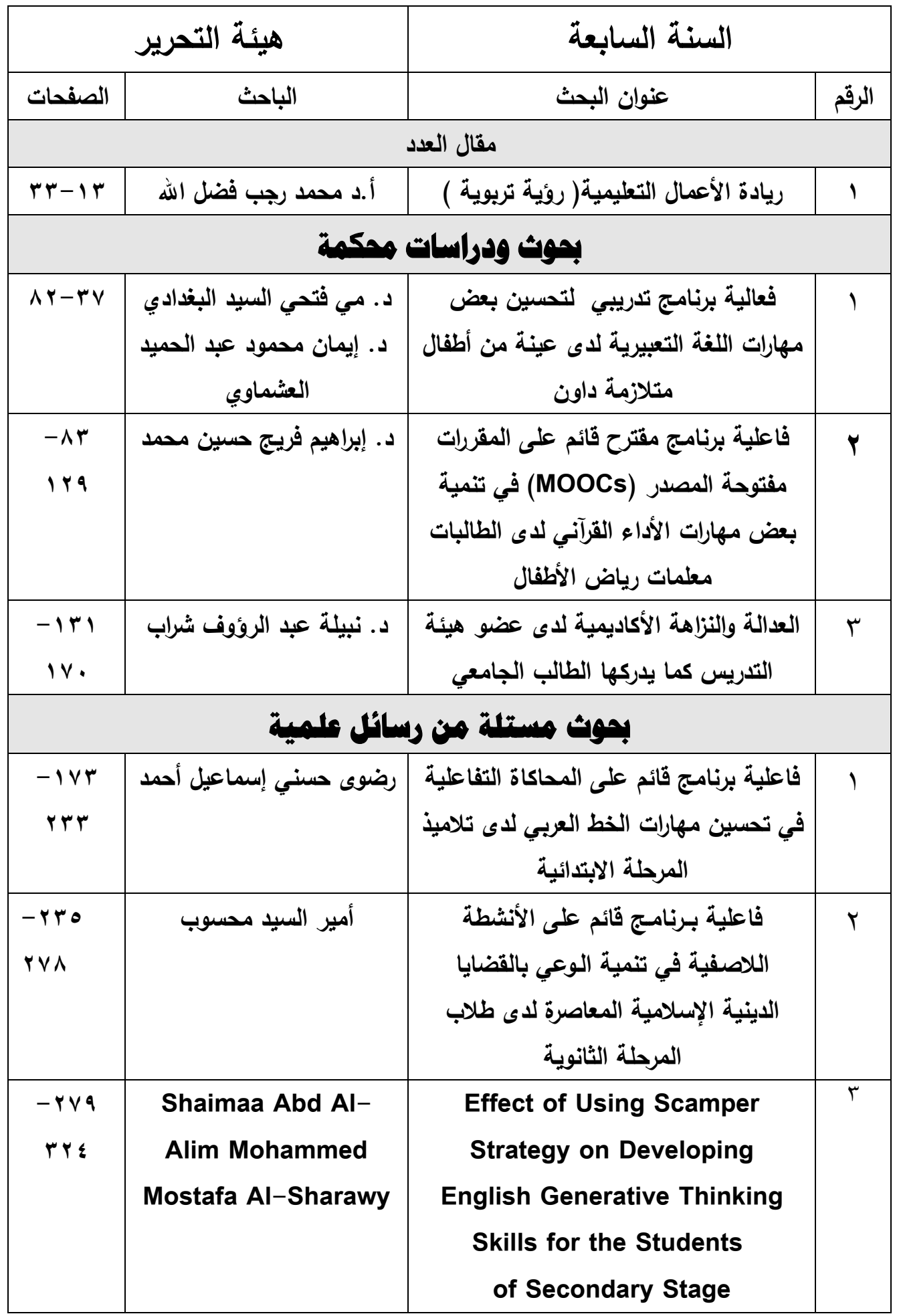




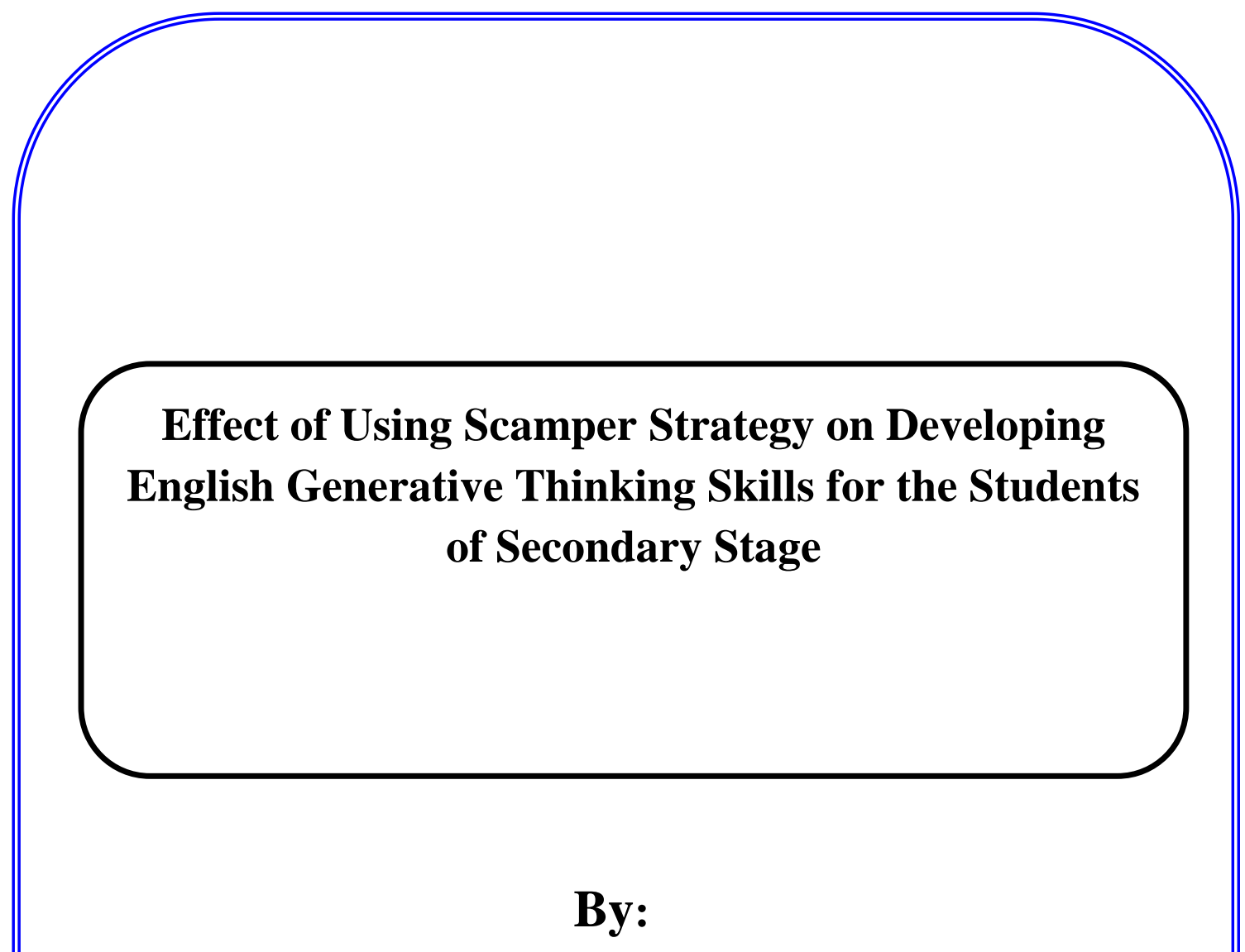

Shaimaa Abd Al-Alim Mohammed Mostafa Al-

Sharawy

Faculty of Education

Arish University 


\title{
Effect of Using Scamper Strategy on Developing English Generative Thinking Skills for the Students of Secondary Stage
}

\author{
Shaimaa Abd Al-Alim Mohammed Mostafa Al-Sharawy
}

Faculty of Education - Arish University

\section{Abstract:}

This study aimed at investigating the effect of using Scamper strategy on developing English generative thinking skills for the students of the first year secondary stage. The study group consisted of (18) students at Al-Arish Secondary Institute for girls, Al-Arish city, North Sinai Governorate. They were assigned to one study group and to receive the experimental training. Four units of the English course (Hello 7) in the first year were selected and were adapted in the light of Scamper strategy. The instruments and materials included: (1) a generative thinking skills checklist, (2) a generative thinking skills pre-post test and (3) a teacher's guide. The generative thinking skills prepost test was administered before and after the intervention. The results proved that Scamper strategy had a positive effect on improving first year secondary stage students' fluency and flexibility. Also, the results proved that Scamper strategy positively affected first year secondary stage students' originality skill. So, Scamper strategy had a large effect on developing the English generative thinking skills for the first year secondary stage students.

Key words: Scamper strategy and generative thinking skills 


\section{Introduction}

Generating ideas with brainstorming is one of the oldestestablished techniques for idea generation. Brainstorming is the catch-all description of idea-generation sessions with groups or teams. Many years ago, brainstorming had a precise definition, before becoming the preferred term for any kind of group idea generation (Cox, 2012). Generative learning theory does not assume dominance of the role of the learner or the instructor or instruction, but participation in the process (Grabowski, 2004, 741). Herring, Jones and Brain $(2009$, 5) stated that brainstorming was the first idea generation technique. It is often referred to as, "the mother of all idea generation techniques". Glenn (1997) stated that Scamper stimulates the thought process and encourages creativity. He added that just pick an object and use the process to brainstorm ways to alter or improve the object. Sullivan $(2016,25)$ adapted ways to generate ideas:

1. Competitive Analysis.

2. The Scamper Method.

3. Force Fitting.

4. Nature Walk.

5. Similar Industry.

Lin, Hong, Hwang and Lin $(2006,5)$ stated that Scamper is a brainstorming method that builds one idea into several ones by asking directed questions about the actions represented by 
the Scamper acronym: substitute, combine, adapt, modify, put to other uses, eliminate, rearrange or reverse. Animasahum $(2014,106)$ stated that Scamper is an acronym which stands for Substitute, Combine, Adapt, and Modify, Put to other uses, Eliminate, and $\mathrm{Re}$-arrange or Reverse. It means that one can substitute the present action for another, combine the present with another and adapt to the environmental demand, whereby one needs to modify to suit the current demand, put to other uses than the conventional, eliminate errors and rearrange for optimal use or productivity. Serrat (2009) asserted that ideas are not often plucked out of thin air. Scamper uses a set of directed questions to meet an opportunity or resolve a problem. It can also turn a tired idea into something new and different.

\subsection{Statement of the problem:}

First year secondary stage students face some difficulties during generating ideas. They cannot speak or write fluently or correctly. They encounter difficulty in recalling information from memory, integrating what they already know to what they are learning, difficulty in organizing what they already know and what they are learning and spurring new ideas. The current study attempted to help students overcome such difficulties through using Scamper strategy.

\subsection{Aim of the study:}


The present study aimed at investigating the effect of Scamper strategy on developing English generative thinking for the first year secondary stage students.

\subsection{Significance of the study:}

The present study may be useful in two aspects:

\section{The theoretical aspect:}

1- The study may direct educationalists to use Scamper strategy on developing generative thinking because it is consistent with the modern trends that call for the students' active learning strategies.

2- It may direct curriculum planners to implement Scamper strategy in the various programs and courses.

3- It may encourage researchers to conduct more researches about Scamper strategy and other skills in English and other different kinds of thinking.

\section{Practical aspect}

- The study may help teachers to develop their methods of teaching using Scamper strategy on developing generative thinking.

- It may train teachers and students on using Scamper strategy on developing generative thinking.

- It may provide teachers with a teacher's guide based on Scamper strategy to help students on developing generative thinking skills. 


\subsection{Questions of the study:}

Questions of the present study are as follows:

1- What are the required EFL generative thinking skills for the first year secondary stage students?

2- To what extent do they possess such skills?

3- What is the effect of using Scamper strategy on developing the first year secondary stage students' fluency skill?

4- What is the effect of using Scamper strategy on developing the first year secondary stage students' flexibility skill?

5- What is the effect of using Scamper strategy on developing the first year secondary stage students' originality skill?

6- What is the effect of using Scamper strategy on developing English generative thinking skills for the students of secondary stage?

\subsection{Hypotheses of the study:}

1. There is a significant statistical difference between the mean scores of the study group students in fluency skill and its subskills at 0.01 level in pre-post test, and this difference is in favor of post implementation.

2. There is a significant statistical difference between the mean scores of the study group students in flexibility skill and its subskills at 0.01 level in pre-post test, and this difference is in favor of post implementation. 
3. There is a significant statistical difference between the mean scores of the study group students in originality skill and its sub-skills at 0.01 level in pre-post test, and this difference is in favor of post implementation.

4. There is a significant statistical difference between the mean scores of the study group students in generative thinking skills as a whole in pre-post test at 0.01 level, and this difference is in favor of post implementation.

5. There is a significant acceptable effectiveness for using scamper strategy in developing English generative thinking skills for the students of secondary stage.

6. There is a significant effect size for using scamper strategy in developing English generative thinking skills for the students of secondary stage.

\subsection{Definition of terms:}

\section{6. 1 Scamper strategy:}

Scamper is an acronym of the seven letters serving as the initial letters that form an idea spurring checklist. This strategy provokes students' minds and spurs the production of ideas with open- ended questions in search of new, different and unique ideas that may lead to the solution of problems. Through Scamper strategy one may also be evoked the need "to run playfully about in one's mind in search of ideas (Michalko, 2006)."

The researcher can define Scamper as follows: 
Scamper is an acronym with seven letters and each letter of them represents one of seven different strategies; substitute, combine, adapt, modify, put to other uses, eliminate, and reverse or rearrange. These strategies spur different and unique ideas in answer to open- ended questions since Scamper strategy is based on that everything new is an alteration of something that is already existed.

Scamper strategy is operationally defined as: the strategy that may help first year secondary stage students to develop English generative thinking skills.

\subsubsection{Generative Thinking:}

By definition, Wittrock (1989) stated that learners should become accountable and responsible in learning and mentally active in constructing relationships between what they know and what they are learning.

Generative Thinking is operationally defined as: a type of thinking that helps first year secondary stage students to spur or generate new ideas through memory storage and build new relationships between what they already know and what they are learning.

\subsection{Scamper strategy:}

Scamper is best used to broaden conceptual understanding of a topic or subject area. Students can use the SCAMPER method in various ways. First, the problem, challenge, idea, or goal that you want to accomplish should be 
defined. Then, either sequentially work through the SCAMPER idea checklist to help generate ideas for a change, or skip around or use a few selected ones (Conklin, 2012, 187).

\subsubsection{Scamper Acronym}

Each of the letters in the Scamper acronym stands for a stage in the process (Michalko, 2006). The letters include the following elements:

$\mathrm{S}$

Substitute

Substitutions is a trial-and-error method where you can try things out, see if it works, then try something different.

Combine

Combining involves synthesis, the process of

C combining previous ideas or things together to create something new.
A Adapt

Think about what is already known about the problem and how others are solving it. Become aware of the process others are using.
M Modify (also , Magnify or Minify)
When you modify or alter something, you reflect on what is needed to support and make it better, greater, simpler, or even more complex. Magnifying will concentrate on making things bigger, thicker, stronger, or more intense. Minifying will concentrate on making things 
lighter, slower, less frequent, or reduced in some capacity.

P Put Consider ways that the target can be used other to than originally intended.

other

uses

E To remove or omit part or all of a particular Eliminate quality. If using elaborate, to add more details. (also,

Elaborate)

When using reverse, focus on the opposite or

$R$ contrary meaning. When using rearrange, Reverse consider how the change of order or sequence (also, would affect the target or challenge.

Rearrange)

\subsection{Scamper Processes:}

Thinking and Feeling Processes (Eberle, 1996, 2-3)

Thinking Processes:

Fluent Thinking consists of the generation of a quantity of ideas, plans, or products. The intent is to build a large store of information or material for selective use at a later time. 
Flexible Thinking provides for shifts categories of thought. It involves detours in thinking to include contrasting reasons, differing points of views, alternatives plans, and the various aspects of a situation. A variety of kinds of ideas and differing approaches are considered. Originality is the production of unusual or unanticipated responses. It is characterized by uniqueness and novelty. Responses may be considered original if they are clever, remote, individualistic, uncommon, inventive, or creative in nature.

Elaborative Thinking is the ability to refine, embellish, or enrich an idea, plan, or product. It involves the addition of new and necessary details for clear and complete communication. It is an elegant response, an ornamented idea, or an adorned expansion upon things. Elaboration provides illuminating descriptive dimensions leaving very little to the imagination.

\section{Feeling Processes}

Curiosity is evidenced by inquisitiveness, a strong desire to know about something. It is exploratory behavior directed toward acquiring information. It involves the use of all the senses to investigate, test out, and to confirm guesses and hunches about the unfamiliar or unknown.

Willingness to Take a Calculated Risk is activity that involves speculation, prediction, wisdom, and foresight. The probability of success and the chance of failure are estimated before action is taken. Risk taking is characterized by the will, disposition, and 
desire to set greater goals in anticipation of greater gains. Consideration for the elements of chance, liking the unknown, adventure, and a tolerance for insecurity are traits common to the risk taker. He or she may also be described as perceptive, inquiring, intuitive, and predictive.

Preference for Complexity is a willingness to accept a challenge. It represents a desire to work with or handle involved details and an inclination to dig into knotty problems. Challenges may be in the form of intricate ideas, difficult problems, complex designs, or complicated theories.

Intuition is perceptive quality that involves quick and keen insight. It is a direct perception of truth or fact independent of reasoning processes. It is the immediate apprehension of untaught knowledge.

Both the thinking and feeling processes and the Scamper Techniques have value for day-to-day living and learning. When used individually or in combination, the processes and techniques may be used for a variety of thinking and doing activities, such as preparing a menu, planning an instructional unit, redecorating a room, or revising the family budget. When considered as a means to improve life through the use of one's imagination talent, shouldn't everybody Scamper?

\subsection{Purposes of Scamper Strategy:}

Eberle (2008) showed that Scamper strategy aimed at: 
-Encouraging learners to spur creative ideas about a subject or topics that are presented to them.

-Developing thinking skills generally and the productive thinking particularly among learners.

-Developing the skill of spurring new ideas, urging learners' curiosity and running risks.

-Developing learner's skill to ask different open -ended questions.

-Developing imagination especially creative imagination of learners.

-Building positive impressions towards thinking, imagination and creativity.

-Training learners to benefit from the ideas of others through developing them and building upon them.

\subsection{Generative thinking:}

\subsubsection{Generative thinking:}

. Herring et al. (2009) stated that brainstorming is an important idea generation technique. Hudson (2010) considered that speed thinking is a generative thinking system that enables any individual or team to deliberately and consciously accelerate the pace at which they normally think and act. Ismail (2011) stated that generative thinking is an active process in which students construct relationships between what they already know and what they are learning. 


\section{8. 2The phases of the Generative Learning Model}

Osborne and Freyberg (1985) stated that the generative learning model (GLM) consists of four instructional phases which are as follows:
(1) Preliminary phase
(2) Focus phase
(3) Challenge phase
(4) Application phase

\subsubsection{The Elements of the Generative Learning Model}

Ismail (2011) focuses on the following as the elements of the generative learning model (GLM):

- Recall

- Integration

- Organization

- Elaboration

\subsection{Activities of the Generative Learning Model:}

The generative learning activities that promote understanding between instruction and prior knowledge include the following: (Kish, 2008)

- Demonstrations

- Metaphors

- Analogues

- Examples

- Pictures

- Applications 
- Interpretations

The generative learning activities that promote understanding among concepts presented in instruction include the following:

- Titles

- Headings

- Questions

- Objectives

- Summaries

- Graphs

- Tables

- Main ideas

Ismail (2011) stated the activities of generative learning:

- Activities that spur regulated relationships.

- Activities that spur integrated relationships.

\subsection{Components for generative thinking}

Chesters (2012) stated four components for generative thinking
(1) wonder,
(2) production,
(3) synectics, and fluency.

\subsection{Rules for generating ideas:}

Sullivan (2016) adapted four rules for generating and evaluating ideas. The four rules for generating ideas include:

1. Defer Judgment.

2. Strive for Quantity.

3. Use your Imagination.

4. Build on other Ideas. 


\subsection{Review of related literature:}

There are several studies conducted on Scamper and generative learning as follows: A study by Fahmy (2017) investigated the effectiveness of using Scamper-based in teaching story to enhance EFL stage primary pupils' speaking skills. A quasi-experimental design with two groups was used. The sample of the study consisted of sixty pupils randomly selected from primary six. Thirty pupils represented the experimental group and thirty pupils represented the control group. A pre-post test and Scamper-based activities were used as the instruments of the study. Results revealed the effectiveness of using Scamper-based in teaching story to enhance EFL stage primary pupils' speaking skills A study by Ozyaprak (2016) aimed at investigating the effect of Scamper on developing creative thinking skills. A one-group design was used in this study. The study group consisted of (14) participants, who were assigned to receive the experimental training. The researcher developed a unique program for the experimental group. The findings of the study revealed that Scamper training significantly increased the participants' creative thinking.

A study by Islam (2016) investigated the effect of Scamper on the creative problem solving skills and academic achievements of students. A group of 40 participants were assigned to either an experimental group or a control group. The findings of the 
study revealed that Scamper had a significant effect on the creative problem solving skills and academic achievements of students.

Idek (2016) conducted a study to investigate whether Scamper can facilitate critical and creative thinking in writing tasks in composing short stories and poems. Twelve secondary school students were assigned into Group1 that composed short stories and Group 2 that wrote poems using Scamper. Pre-test and post-test were administered to the study samples. The findings showed that students who applied Scamper in composing short stories performed better on the post-test than the group that used it in writing poems. Therefore, the application of Scamper in improvising short stories is more effective in the development of critical and creative thinking.

A study by Nassef (2015) showed the effectiveness of the enrichment program based in the theory of Scamper in the development of language skills and creative thinking for the gifted with learning disabilities. The experimental method was used in the study. Two groups were used and the program was applied to the experimental group. A sample of (40) female students from the third grade in the typical pyramid secondary schools was divided into experimental and control groups. A diagnostic test, a creative thinking test and a training program were used in the study. They were used to enrich the language skills. The findings revealed that the enrichment program 
significantly developed the language skills and creative thinking for the gifted with learning disabilities.

Radwan's study (2015) aimed at discovering the effectiveness of a Scamper program in developing creative writing skills in the English language for the female talented students in the secondary stage. Two groups were used. One group served as an experimental group and the other group served as a control group. The quasi experimental group was used. The instruments of the study were a creative writing skills checklist, a creative writing test and a Scamper program, which were prepared by the researcher. The results proved the effectiveness of the Scamper program in developing creative writing skills.

A study by Chulvi, Cruz, Mulet and Zambrano (2013) showed the influence of the type of idea-generation method on the creativity of solutions. Sixteen teams were the participants in the experiment. Seven of the teams used the Scamper intuitive method and another seven teams used the TRIZ logical method. Two teams acted as control. Results showed differences in these parameters in the different methods used in the experiment.

A study by Rietzschel, Nijstad and Stroebe (2006) compared two groups with interactive and nominal brainstorming on idea generation and selection. Nominal groups generated more ideas 
than interactive groups. Results showed that high productivity in brainstorming is not sufficient to lead to better solutions.

A study by Kramer, Kuo and Dailey (1997) investigated the impact of brainstorming technique on subsequent group processes beyond generating ideas. Brainstorming and nominal group members were more satisfied, felt their groups used a more effective process, and felt they communicated more effectively and positively than untrained groups.

A study by Johnsey, Morrison and Ross (1992) revealed the effectiveness of using elaboration strategies training in computer-based instruction to promote generative learning. Subjects were 80 administrative assistants (20 per treatment). Results are interpreted as favoring the use of elaboration strategies, particularly when taught by embedded training, for promoting generative learning.

\subsection{Scamper and Generative thinking connection:}

\section{10.1 Idea-Generating Strategies:}

- Conklin $(2012,158)$ illustrated that the ability to generate many ideas is both helpful and desirable in any given situation in order to reach the best solutions. A person is more apt to come up with great ideas if he or she has many ideas from which to choose. The ability to generate many ideas works in the classroom as students decide on topics for writing, ways to solve math problems, the types of experiments to conduct, and the possible solutions to a problem from the past. 
The idea-generating strategies include the following:

1. Brainstorming

3. Scamper

organizers
2. Brain writing

4. Thinking

- Lin et al. (2006) selected top ten techniques to be as strategies for generating ideas:

1. Brainstorming

2. K. J.

Method

3. Checklist

4. Scamper

5. $1 \mathrm{H} 5 \mathrm{~W}$

6. TRIZ

7. Delphi Method 8-Why Method

9. NGT (Nominal Group Technique) 10. Mind Mapping Technique

\section{Method}

\subsection{Design of the study:}

The researcher used the quasi- experimental design with one group to recognize the effect of Scamper strategy on developing English generative thinking skills in English for the students of secondary stage. The study group was selected from first year secondary stage students. Before conducting the experiment, the study group was tested. During the experiment the study group was taught using Scamper strategy. At the end of the experiment, the study group was tested.

\section{2 Participants of the study:}


The study participants consisted of one group of first year secondary stage students, at Al-Arish secondary Institute for girls (Al-Azher Al-Sharif), Al- Arish city, North Sinai Governorate. The study group consisted of (18) participants. They were assigned to receive experimental training. The researcher adapted four units in the light of Scamper strategy to help the students develop English generative thinking skills.

\section{3 Instruments and materials of the study:}

1. A checklist of generative thinking skills suitable for the first year secondary stage students

2. A generative pre-post test

3. A teacher's guide of adapted lessons according to Scamper strategy

\section{3. 1 Description generative thinking pre-post test:}

The generative thinking pre-post test was prepared by the researcher to be taken by first year secondary stage students to measure their entry level in generative thinking skills. The Generative thinking pre-post test has five passages. They are followed by twenty- two (22) questions. The following table contains the skills and sub-skills that are measured by the prepost test.

\section{3. 2 Generative thinking skills and their sub-skills:}

According to reviewing literature and related studies about Scamper and generative thinking a list of skills and sub-skills of generative thinking can be concluded: According to Eberle 
$(1996,2)$ and Gowda $(2015,79)$ there are three certain generative skills:

1- Fluency skill: They consist of the generation of a quantity of ideas, plans, or products. The intent is to build a large store of information or material for selective use at a later time.

2- Flexibility skill: These provide for shifts categories of thought. This involves detours in thinking to include contrasting reasons, differing points of views, alternatives plans, and the various aspects of a situation. A variety of kinds of ideas and differing approaches are considered. Originality is the production of unusual or unanticipated responses. It is characterized by uniqueness and novelty. Responses may be considered original if they are clever, remote, individualistic, uncommon, inventive, or creative in nature.

3- Originality skill: These involve the ability to think in uncommon modes with clever, unique and unusual concepts. It helps a person see remote and far-reaching consequences of what on the surface may appear to be small changes.

\section{3. 3 Description of the sub- skills of generative thinking:}

According to Content Standards Document for PreUniversity Education (2009), there is a joint standard among English skills that learners practice higher level thinking skills while listening, speaking, reading and writing.

\section{Fluency skill:}

1. Generate varied ideas related to the topic in hand 
2. Recall required information

3. Express ideas clearly and effectively

4. Support viewpoints on an issue

5. Use various vocabulary related to the issue in hand

\section{Flexibility skill:}

1. Provide a variety of responses

2. Develop appropriate vocabulary

3. Provide a structured argument to support one's opinions Originality skill:

1. Express unfamiliar and unique ideas using a wide range of vocabulary

2. Make reasonable and feasible predictions

3. Express conclusions logically

\section{4 Experimental procedures:}

The researcher reviewed the related literature and previous studies concerning the variables of the study (Scamper strategy and generative thinking skills) to benefit from them in designing the instruments of the present study and the pre-post test. A checklist of generative thinking skills required for the first year secondary stage students was prepared and validated it. The generative thinking skills pre-post test was designed and validated it. A teacher's guide was prepared to help the teachers teach according to Scamper strategy. The study group was pre tested. The study group was taught using the teacher's guide. The study group was post tested. The results of the pre-post 
test were compared. The data was treated statistically using the appropriate statistical devices. The results were interpreted and discussed. Conclusions, recommendations and suggestions were presented in the light of the results.

\subsection{Pre-testing:}

The study group was pre-tested on their generative skills test on $25^{\text {th }}$ October 2017 . Data were analyzed statistically. The results showed that Scamper strategy had a large effect on developing English generative thinking for the secondary stage students.

\section{4. 2 Teaching the adapted units:}

Having been pre-tested, the students were taught the generative skills via the units adapted. Session one consisted of a brief introduction about Scamper strategy followed by a pre test. The following sessions involved presenting the adapted units in the light of Scamper strategy to come up with so many ideas that were varied, unique and unusual to develop English generative thinking skills.

\section{4. 3 Post-testing:}

At the end of the $6-$ week period on $5^{\text {th }}$ December 2017 , the study group was post tested using the same test and under the same conditions as the pre test. The results showed the effectiveness of Scamper strategy in developing English generative thinking for the secondary stage students. 


\section{Results and Discussion:}

\subsection{Testing hypothesis (1):}

There is a significant difference statistical between the mean scores of the study group students in fluency skill and its sub-skills in the generative thinking skills pre-post test.

In order to test the hypothesis, the Paired-Samples $\mathrm{t}-$ test is computed between the mean scores of the study group students in fluency skill and its sub-skills in the pre-post test. The procedure is executed by SPSS program. Results are presented in the following table:

Table (1) Results of $t$-test of scores of the study group students in fluency skill and its sub-skills in the generative thinking skills pre-post test

\begin{tabular}{|c|c|c|c|c|c|c|c|c|c|}
\hline Skills & $\begin{array}{l}\text { Tes } \\
\mathbf{t}\end{array}$ & $\mathbf{N}$ & Mean & $\begin{array}{l}\text { Std. } \\
\text { Deviatio } \\
\text { n }\end{array}$ & Df & Corr. & $\begin{array}{l}t- \\
\text { Value }\end{array}$ & Sig. & Result \\
\hline \multirow{2}{*}{$\begin{array}{l}\text { generate } \\
\text { varied } \\
\text { ideas } \\
\text { related to } \\
\text { the topic } \\
\text { in hand }\end{array}$} & Pre & \multirow[b]{2}{*}{$\begin{array}{l}1 \\
8\end{array}$} & 0.917 & 1.437 & \multirow[b]{2}{*}{$\begin{array}{l}1 \\
7\end{array}$} & \multirow[b]{2}{*}{$\begin{array}{l}0.68 \\
9\end{array}$} & \multirow[b]{2}{*}{6.886} & \multirow[b]{2}{*}{$\begin{array}{l}0.00 \\
0\end{array}$} & \multirow{2}{*}{$\begin{array}{l}\text { Significa } \\
\text { nt at the } \\
0.01 \\
\text { level (2- } \\
\text { tailed) }\end{array}$} \\
\hline & $\begin{array}{l}\text { Pos } \\
t\end{array}$ & & 3.444 & 2.148 & & & & & \\
\hline \multirow{2}{*}{$\begin{array}{l}\text { recall } \\
\text { required } \\
\text { informatio } \\
n\end{array}$} & Pre & \multirow[b]{2}{*}{8} & 3.667 & 2.196 & \multirow{2}{*}{$\begin{array}{l}1 \\
7\end{array}$} & \multirow{2}{*}{$\begin{array}{l}0.07 \\
6\end{array}$} & \multirow{2}{*}{4.500} & \multirow{2}{*}{$\begin{array}{l}0.00 \\
0\end{array}$} & \multirow{2}{*}{$\begin{array}{l}\text { Significa } \\
\text { nt at the } \\
0.01 \\
\text { level (2- } \\
\text { tailed) }\end{array}$} \\
\hline & $\begin{array}{l}\text { Pos } \\
t\end{array}$ & & 5.994 & 0.024 & & & & & \\
\hline
\end{tabular}




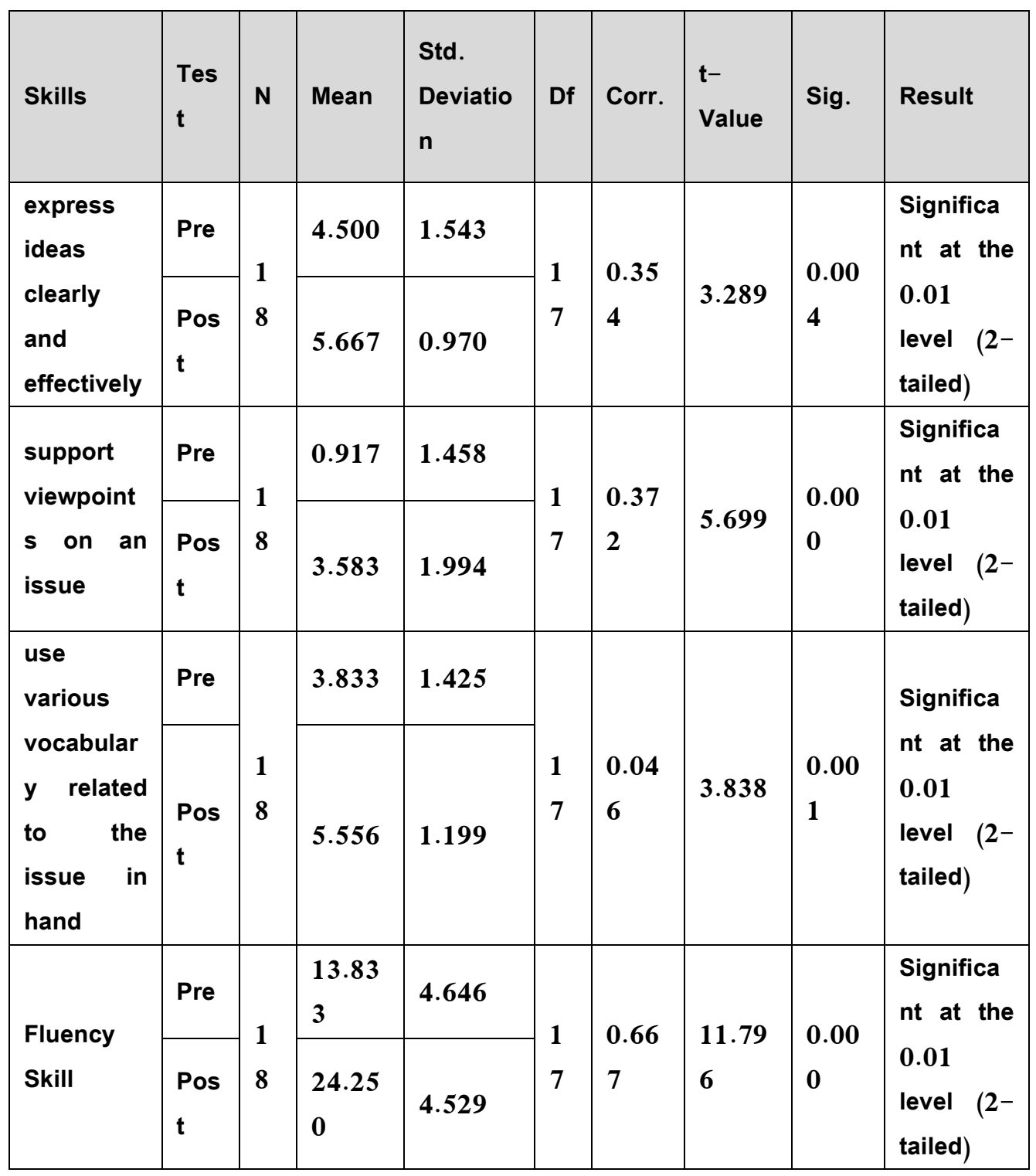

Figure (1) Comparison between the mean scores of the study group students in fluency skill and its sub-skills in the generative thinking skills pre-post test 


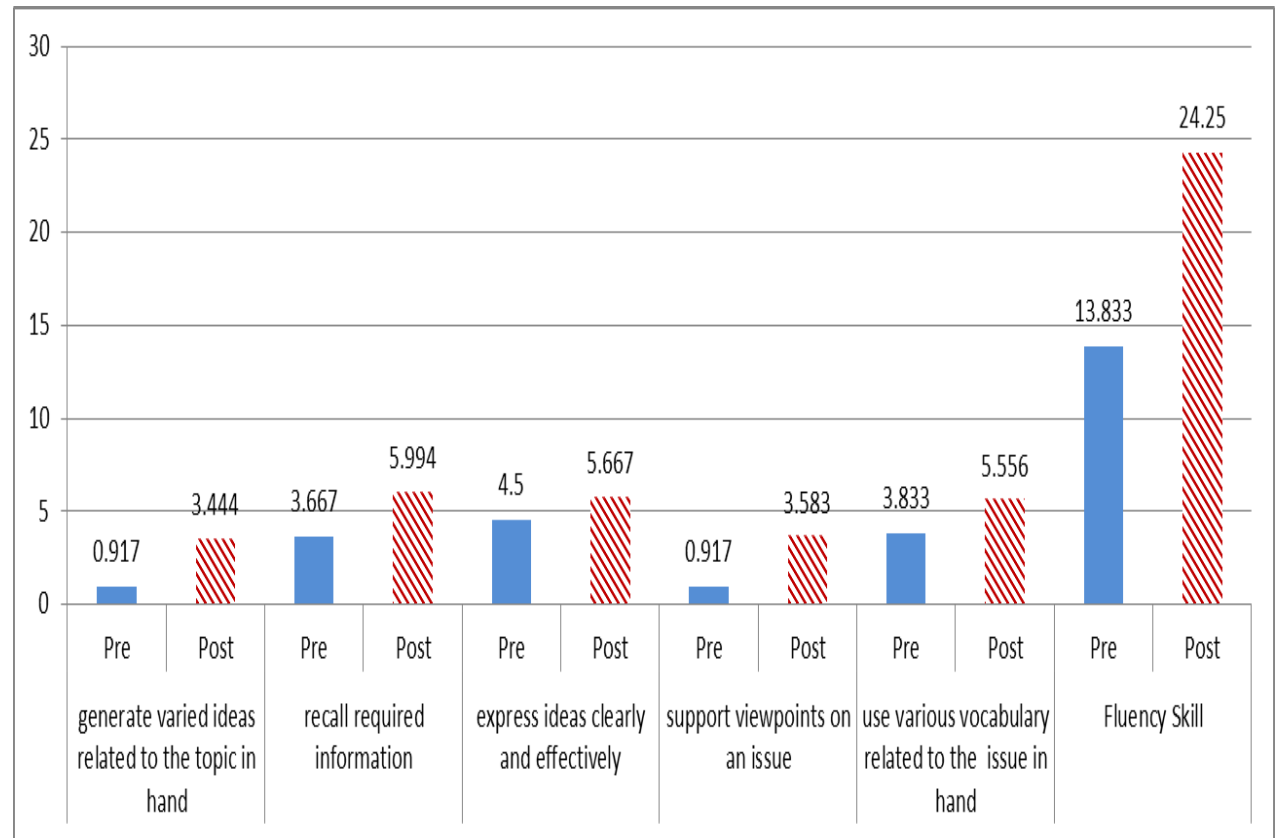

As shown in the previous table and figure, there is a significant statistical difference at the 0.01 level (2-tailed) and degree of freedom at (17), indicating that there is a significant statistical difference between the levels of the study group students in fluency skill and its sub-skills before and after teaching by Scamper strategy. So the hypothesis is accepted. This reflects that there is a significant statistical difference between the mean scores of the study group students in fluency skill and its sub-skills in pre-post test, and this difference is in favor of post implementation.

\section{2 Testing hypothesis $(2)$ :}

There is a significant statistical difference between the mean scores of the study group students in flexibility skill and its sub-skills in the generative thinking skills pre-post test. 
In order to test the hypothesis, the Paired-Samples $t$-test is computed between the mean scores of the study group students in flexibility skill and its sub-skills in the pre-post test. The procedure is executed by SPSS program. Results are presented in the following table:

Table (2) Results of $t$-test of scores of the study group students in Flexibility skill and its sub-skills in the generative thinking skills pre-post test

\begin{tabular}{|c|c|c|c|c|c|c|c|c|c|}
\hline Skills & $\begin{array}{l}\text { Tes } \\
t\end{array}$ & $\mathbf{N}$ & Mean & $\begin{array}{l}\text { Std. } \\
\text { Deviatio } \\
\text { n }\end{array}$ & Df & Corr. & $\begin{array}{l}t- \\
\text { Value }\end{array}$ & Sig. & Result \\
\hline \multirow{2}{*}{$\begin{array}{l}\text { provide a } \\
\text { variety of } \\
\text { responses }\end{array}$} & Pre & \multirow{2}{*}{$\begin{array}{l}1 \\
8\end{array}$} & 0.222 & 0.428 & \multirow{2}{*}{$\begin{array}{l}1 \\
7\end{array}$} & \multirow{2}{*}{$\begin{array}{l}0.68 \\
1\end{array}$} & \multirow{2}{*}{$\begin{array}{l}4.01 \\
2\end{array}$} & \multirow{2}{*}{$\begin{array}{l}0.00 \\
1\end{array}$} & \multirow{2}{*}{$\begin{array}{l}\text { Significan } \\
t \text { at the } \\
0.01 \text { level } \\
\text { (2-tailed) }\end{array}$} \\
\hline & $\begin{array}{l}\text { Pos } \\
t\end{array}$ & & 2.417 & 2.591 & & & & & \\
\hline \multirow{2}{*}{$\begin{array}{l}\text { develop } \\
\text { appropriat } \\
\text { e } \\
\text { vocabular } \\
\text { y }\end{array}$} & Pre & \multirow{2}{*}{$\begin{array}{l}1 \\
8\end{array}$} & 1.722 & 1.602 & \multirow{2}{*}{$\begin{array}{l}1 \\
7\end{array}$} & \multirow{2}{*}{$\begin{array}{l}0.00 \\
6\end{array}$} & \multirow{2}{*}{$\begin{array}{l}5.45 \\
5\end{array}$} & \multirow{2}{*}{$\begin{array}{l}0.00 \\
0\end{array}$} & \multirow{2}{*}{$\begin{array}{l}\text { Significan } \\
t \text { at the } \\
0.01 \text { level } \\
\text { (2-tailed) }\end{array}$} \\
\hline & $\begin{array}{l}\text { Pos } \\
t\end{array}$ & & 4.167 & 1.015 & & & & & \\
\hline \multirow{3}{*}{$\begin{array}{l}\text { provide a } \\
\text { structured } \\
\text { argument } \\
\text { to support } \\
\text { one's } \\
\text { opinions }\end{array}$} & Pre & \multirow{3}{*}{$\begin{array}{l}1 \\
8\end{array}$} & 0.556 & 0.984 & \multirow{3}{*}{$\begin{array}{l}1 \\
7\end{array}$} & \multirow{3}{*}{$\begin{array}{l}0.38 \\
9\end{array}$} & \multirow{3}{*}{$\begin{array}{l}6.41 \\
8\end{array}$} & \multirow{3}{*}{$\begin{array}{l}0.00 \\
0\end{array}$} & \multirow{3}{*}{$\begin{array}{l}\text { Significan } \\
\mathrm{t} \text { at the } \\
0.01 \text { level } \\
\text { (2-tailed) }\end{array}$} \\
\hline & $\begin{array}{l}\text { Pos } \\
t\end{array}$ & & 3.722 & 2.270 & & & & & \\
\hline & & & & & & & & & \\
\hline \multirow{2}{*}{$\begin{array}{l}\text { Flexibility } \\
\text { Skill }\end{array}$} & Pre & \multirow{2}{*}{$\begin{array}{l}1 \\
8\end{array}$} & 2.500 & 2.503 & \multirow{2}{*}{$\begin{array}{l}1 \\
7\end{array}$} & \multirow{2}{*}{$\begin{array}{l}0.39 \\
2\end{array}$} & \multirow{2}{*}{$\begin{array}{l}7.00 \\
8\end{array}$} & \multirow{2}{*}{$\begin{array}{l}0.00 \\
0\end{array}$} & \multirow{2}{*}{$\begin{array}{l}\text { Significan } \\
t \text { at the } \\
0.01 \text { level } \\
\text { (2-tailed) }\end{array}$} \\
\hline & $\begin{array}{l}\text { Pos } \\
t\end{array}$ & & $\begin{array}{l}10.30 \\
6\end{array}$ & 5.100 & & & & & \\
\hline
\end{tabular}


Figure (2) Comparison between the mean scores of the study group students in flexibility skill and its sub-skills in the generative thinking skills pre-post test

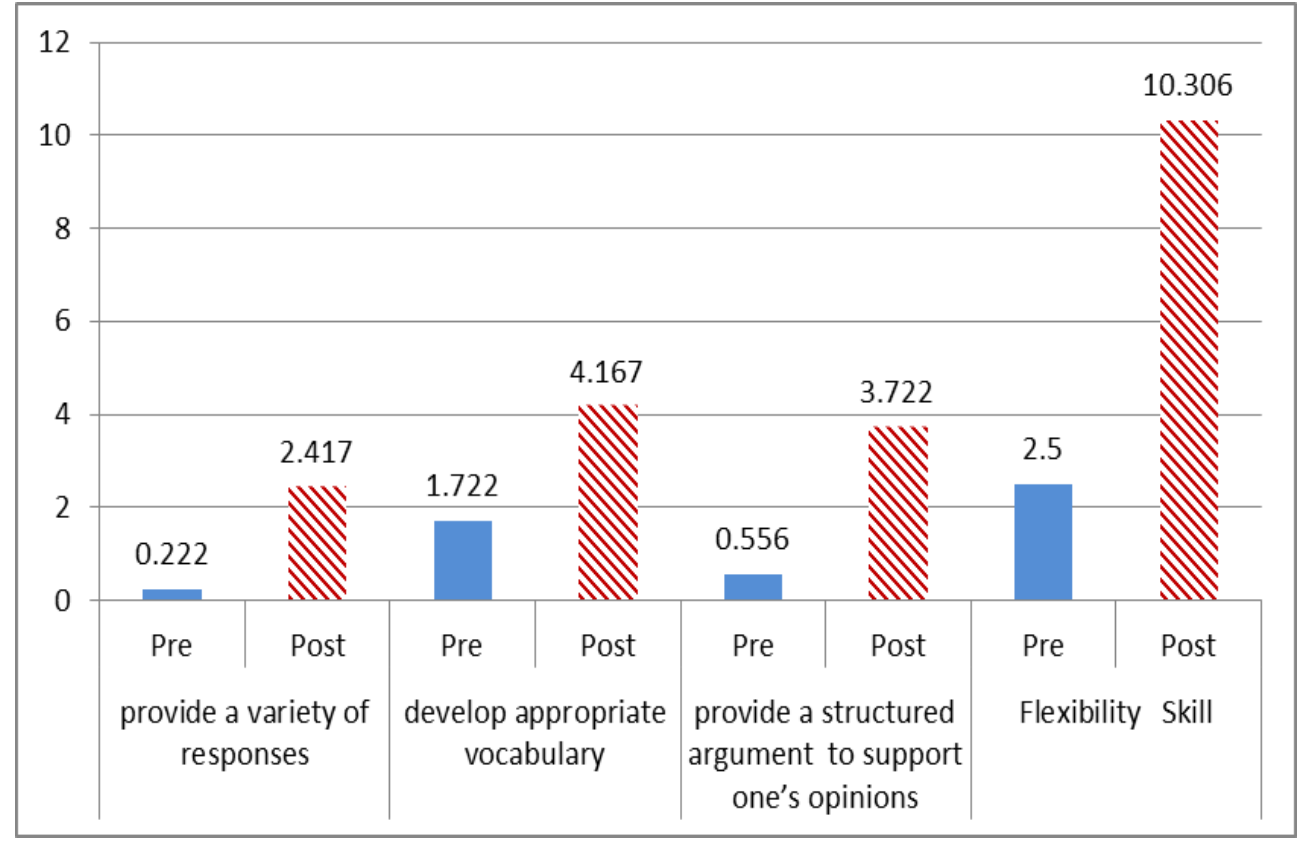

As shown in the previous table and figure, there is a significant statistical difference at the 0.01 level (2-tailed) and degree of freedom at (17), indicating that there is a significant statistical difference between the levels of the study group students in flexibility skill and its sub-skills before and after teaching by Scamper strategy. So the hypothesis is accepted. It means that there is a significant statistical difference between the mean scores of the study group students in flexibility skill and its sub-skills in the pre-post test, and this difference is in favor of post implementation. 


\section{3 Testing hypothesis $(3)$ :}

There is a significant statistical difference between the mean scores of the study group students in originality skill and its sub-skills in the generative thinking skills pre-post test.

In order to test the hypothesis, the Paired-Samples ttest is computed between the mean scores of the study group students in originality skill and its sub-skills in the pre- post test. The procedure is executed by SPSS program. Results are presented in the following table:

Table (3) Results of $t$-test of scores of the study group students in originality skill and its sub-skills in the generative skills of pre-post test

\begin{tabular}{|c|c|c|c|c|c|c|c|c|c|}
\hline Skills & $\begin{array}{l}\text { Tes } \\
\mathbf{t}\end{array}$ & $\mathbf{N}$ & Mean & $\begin{array}{l}\text { Std. } \\
\text { Deviatio } \\
\text { n }\end{array}$ & Df & Corr. & $\begin{array}{l}t- \\
\text { Value }\end{array}$ & Sig. & Result \\
\hline \multirow{2}{*}{$\begin{array}{l}\text { express } \\
\text { unfamiliar } \\
\text { and unique } \\
\text { ideas } \\
\text { using a } \\
\text { wide range } \\
\text { of } \\
\text { Vocabulary }\end{array}$} & Pre & \multirow[b]{2}{*}{$\begin{array}{l}1 \\
8\end{array}$} & 2.250 & 1.683 & \multirow[b]{2}{*}{$\begin{array}{l}1 \\
7\end{array}$} & \multirow[b]{2}{*}{$\begin{array}{l}0.10 \\
1\end{array}$} & \multirow[b]{2}{*}{$\begin{array}{l}3.19 \\
7\end{array}$} & \multirow[b]{2}{*}{$\begin{array}{l}0.00 \\
5\end{array}$} & \multirow[b]{2}{*}{$\begin{array}{l}\text { Significan } \\
t \text { at the } \\
0.01 \text { level } \\
\text { (2-tailed) }\end{array}$} \\
\hline & $\begin{array}{l}\text { Pos } \\
t\end{array}$ & & 3.889 & 1.558 & & & & & \\
\hline \multirow{2}{*}{$\begin{array}{l}\text { Make } \\
\text { reasonable } \\
\text { and } \\
\text { feasible } \\
\text { predictions }\end{array}$} & Pre & \multirow{2}{*}{$\begin{array}{l}1 \\
8\end{array}$} & 1.167 & 1.505 & \multirow{2}{*}{$\begin{array}{l}1 \\
7\end{array}$} & \multirow{2}{*}{$\begin{array}{l}0.13 \\
2\end{array}$} & \multirow{2}{*}{$\begin{array}{l}6.91 \\
1\end{array}$} & \multirow{2}{*}{$\begin{array}{l}0.00 \\
0\end{array}$} & \multirow{2}{*}{$\begin{array}{l}\text { Significan } \\
t \text { at the } \\
0.01 \text { level } \\
\text { (2-tailed) }\end{array}$} \\
\hline & $\begin{array}{l}\text { Pos } \\
t\end{array}$ & & 4.194 & 1.308 & & & & & \\
\hline $\begin{array}{l}\text { express } \\
\text { conclusion }\end{array}$ & Pre & $\begin{array}{l}1 \\
8\end{array}$ & 1.722 & 1.965 & $\begin{array}{l}1 \\
7\end{array}$ & $\begin{array}{l}0.04 \\
1\end{array}$ & $\begin{array}{l}4.63 \\
2\end{array}$ & $\begin{array}{l}0.00 \\
0\end{array}$ & $\begin{array}{l}\text { Significan } \\
t \text { at the }\end{array}$ \\
\hline
\end{tabular}




\begin{tabular}{|c|c|c|c|c|c|c|c|c|c|}
\hline Skills & $\begin{array}{l}\text { Tes } \\
\mathbf{t}\end{array}$ & $\mathbf{N}$ & Mean & $\begin{array}{l}\text { Std. } \\
\text { Deviatio } \\
\text { n }\end{array}$ & Df & Corr. & $\begin{array}{l}t- \\
\text { Value }\end{array}$ & Sig. & Result \\
\hline s logically & $\begin{array}{l}\text { Pos } \\
t\end{array}$ & & 4.556 & 1.617 & & & & & $\begin{array}{l}0.01 \text { level } \\
\text { (2-tailed) }\end{array}$ \\
\hline \multirow{2}{*}{$\begin{array}{l}\text { Originality } \\
\text { Skill }\end{array}$} & Pre & \multirow{2}{*}{$\begin{array}{l}1 \\
8\end{array}$} & 5.139 & 3.826 & \multirow{2}{*}{$\begin{array}{l}1 \\
7\end{array}$} & \multirow{2}{*}{$\begin{array}{l}0.23 \\
2\end{array}$} & \multirow{2}{*}{$\begin{array}{l}6.57 \\
6\end{array}$} & \multirow{2}{*}{$\begin{array}{l}0.00 \\
0\end{array}$} & \multirow{2}{*}{$\begin{array}{l}\text { Significan } \\
t \text { at the } \\
0.01 \text { level } \\
\text { (2-tailed) }\end{array}$} \\
\hline & $\begin{array}{l}\text { Pos } \\
t\end{array}$ & & $\begin{array}{l}12.63 \\
9\end{array}$ & 3.977 & & & & & \\
\hline
\end{tabular}

Figure (3) Comparison between the mean scores of the study group students in originality skill and its sub-skills in the generative thinking skills pre-post test

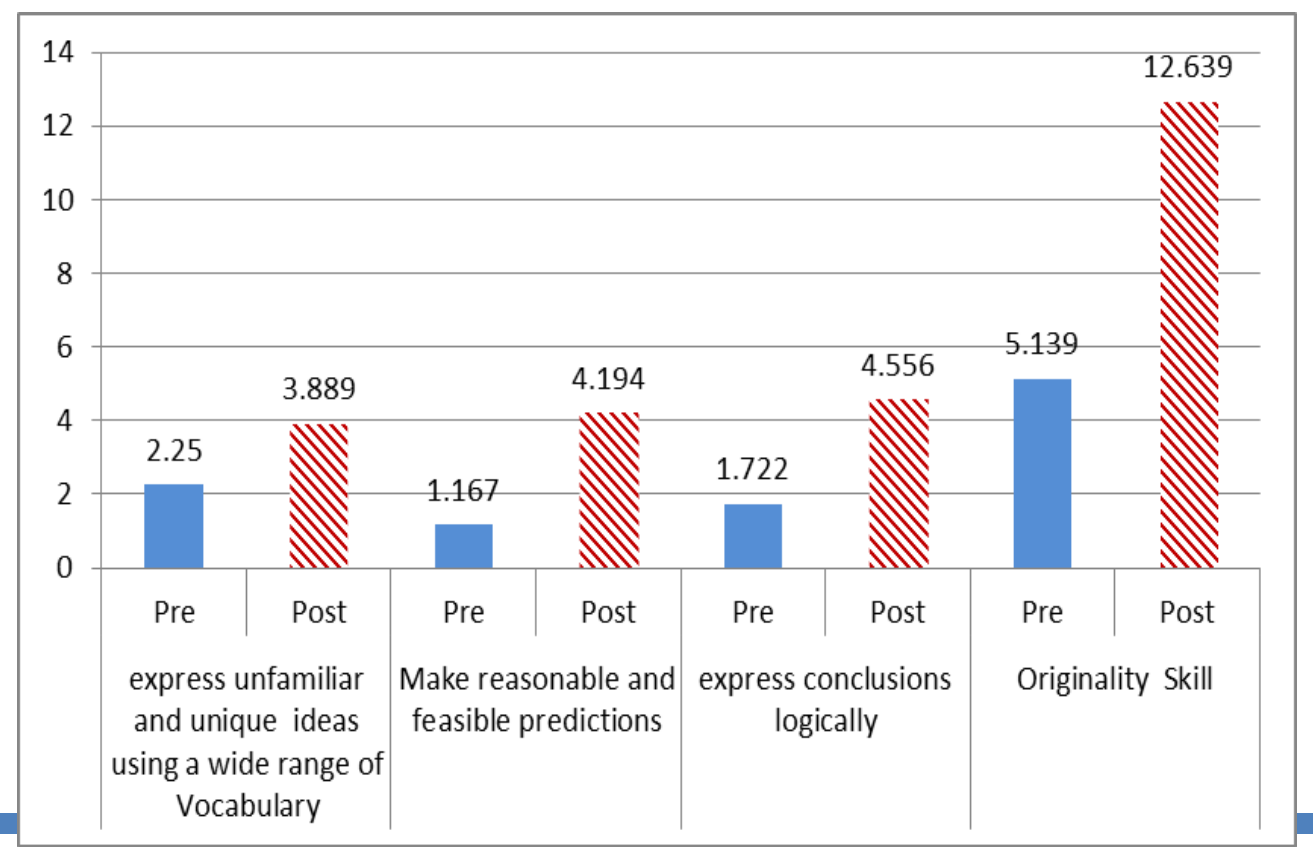


As shown in the previous table and figure, there is a significant statistical difference at the 0.01 level (2-tailed) and degree of freedom at (17), indicating that there is significant statistical difference between the levels of the study group students in originality skill and its sub-skills before and after teaching by Scamper strategy. So the hypothesis is accepted. It reflects that there is a significant statistical difference between the mean scores of the study group students in originality skill and its sub-skills in the pre- post test, and this difference is in favor of post implementation.

\section{4 Testing hypothesis (4):}

There is a significant statistical difference between the mean scores of the study group students in the generative thinking skills as a whole in the pre-post test.

In order to test the hypothesis, the Paired-Samples ttest is computed between the mean scores of the study group students in the generative thinking skills as a whole in the prepost test. The procedure is executed by SPSS program. Results are presented in the following table:

Table (4) Results of $t$-test of scores of the study group students in the generative thinking skills as a whole in the pre-post test 


\begin{tabular}{|c|c|c|c|c|c|c|c|c|}
\hline Test & $\mathbf{N}$ & Mean & $\begin{array}{l}\text { Std. } \\
\text { Deviation }\end{array}$ & Df & Corr. & $\begin{array}{l}t- \\
\text { Value }\end{array}$ & Sig. & Result \\
\hline Pre & \multirow{2}{*}{18} & 21.472 & 8.636 & \multirow{2}{*}{17} & \multirow{2}{*}{0.620} & \multirow{2}{*}{10.666} & \multirow{2}{*}{0.000} & \multirow{2}{*}{$\begin{array}{l}\text { Significant at } \\
\text { the } 0.01 \text { level } \\
(2-\text { tailed })\end{array}$} \\
\hline Post & & 47.194 & 13.025 & & & & & \\
\hline
\end{tabular}

Figure (4) Comparison between the scores of the study group students in the generative thinking skills as a whole in the pre-post test

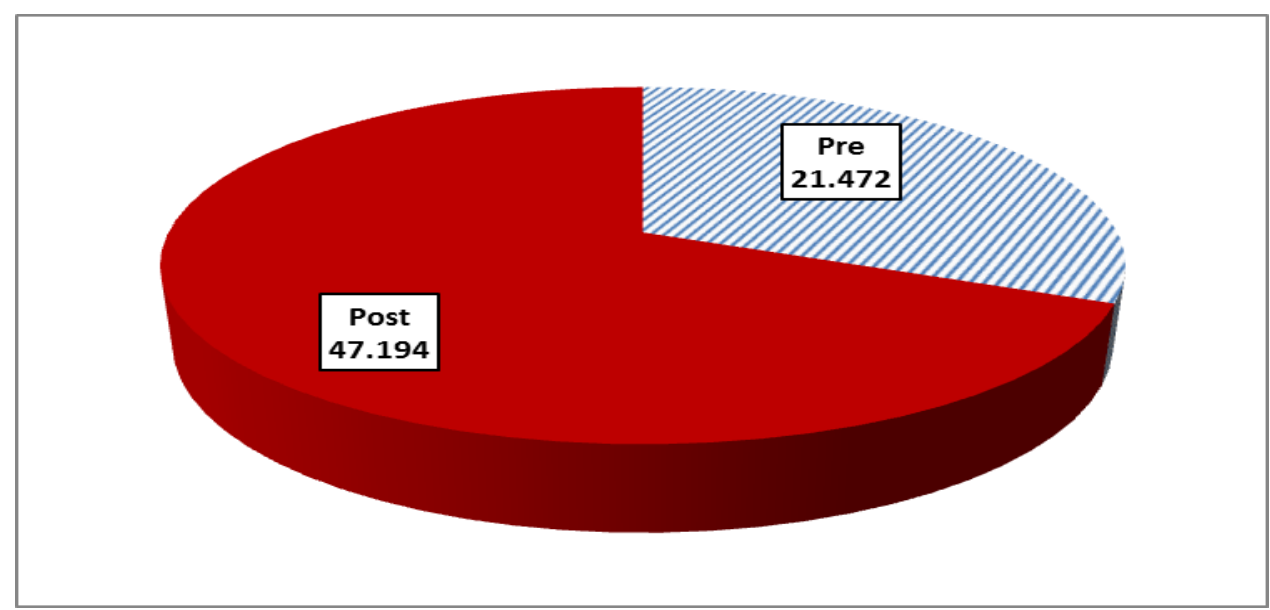

As shown in the previous table and figure, there is a significant statistical difference at the 0.01 level (2-tailed) and degree of freedom at (17), indicating that there is a significant statistical difference between the levels of the study group students in the generative thinking skills as a whole before and after teaching by Scamper strategy. So the hypothesis is 
accepted. It reflects that there is a significant statistical difference between the mean scores of the study group students in the generative thinking skills as a whole in the pre-post test, and this difference is in favor of post implementation.

\subsection{Testing hypothesis (5):}

There is a significant acceptable effectiveness for using scamper strategy in developing English generative thinking skills for the students of secondary stage.

In order to test the hypothesis, the following steps have been taken:

Effectiveness was calculated by applying the H-SGR Formula on the pre-post mean scores of the study group scores using the H-EESC program for calculating the effectiveness and effect size, Results are presented in the following table:

Table (5) effectiveness for using scamper strategy on developing English generative thinking skills

\begin{tabular}{|l|l|l|l|l|}
\hline $\begin{array}{l}\text { Pre- } \\
\text { Mean }\end{array}$ & $\begin{array}{l}\text { Post- } \\
\text { Mean }\end{array}$ & $\begin{array}{l}\text { Max- } \\
\text { Score }\end{array}$ & H-SGR & Effectiveness \\
\hline 21.472 & 47.194 & 66 & 0.39 & $\begin{array}{l}\text { Acceptable } \\
\text { Effectiveness }\end{array}$ \\
\hline
\end{tabular}

Table (6) Reference table of Effectiveness by Haridy's simple gain ratio (H-SGR) (Haridy, 2017)

\begin{tabular}{|l|l|l|}
\hline No & Acceptable & Large \\
Effectiveness & Effectiveness & Effectiveness \\
\hline
\end{tabular}




\begin{tabular}{|l|l|l|}
\hline $0-0.30$ & $0.31-0.70$ & $0.71-1.00$ \\
\hline & & \\
\hline
\end{tabular}

As shown in the previous tables, the results refer to that the effectiveness for using scamper strategy is acceptable. So the hypothesis is accepted. This means that there is a significant acceptable effectiveness for using scamper strategy on developing English generative thinking skills for the students of secondary stage.

\subsection{Testing hypothesis (6):}

There is a significant effect size for using scamper strategy in developing English generative thinking skills for the students of secondary stage.

In order to test the hypothesis, the following steps have been taken:

Effect size was calculated by $\mathrm{t}$ - value between the pre-post means of the study group scores, correlation coefficient, and degree of freedom. And by using the H-EESC program for calculating the effectiveness and effect size, Results are presented in the following:

Table (7) effect size of using scamper strategy on developing English generative thinking skills

\begin{tabular}{|c|c|c|c|c|c|c|}
\hline \multirow{2}{*}{$\begin{array}{l}\text { Degrees of } \\
\text { Freedom } \\
(d f)\end{array}$} & \multirow{2}{*}{$\begin{array}{l}\mathrm{t}- \\
\text { Value }\end{array}$} & \multirow{2}{*}{$\begin{array}{l}\text { Pearson's } \\
\text { Correlation }\end{array}$} & \multicolumn{2}{|c|}{ Cohen's $d$} & \multicolumn{2}{|c|}{$\begin{array}{l}\text { Eta Squared } \\
\left(\eta^{2}\right)\end{array}$} \\
\hline & & & Value & $\begin{array}{l}\text { Effect } \\
\text { Size }\end{array}$ & Value & $\begin{array}{l}\text { Effect } \\
\text { Size }\end{array}$ \\
\hline
\end{tabular}




\begin{tabular}{|l|l|l|l|l|l|l|}
\hline 17 & 10.666 & 0.620 & 2.192 & Huge & 0.87 & Huge \\
\hline
\end{tabular}

Table (8) Reference table of Effect Size by Cohen's (d) and Eta Squared

\begin{tabular}{|c|c|c|c|c|c|c|}
\hline \multirow[b]{2}{*}{ Coefficient } & \multicolumn{6}{|c|}{ Effect Size } \\
\hline & Trivial & Small & Medium & Large & $\begin{array}{l}\text { Very } \\
\text { Large }\end{array}$ & Huge \\
\hline$D$ & $\begin{array}{l}\text { Less } \\
\text { Than } \\
0.20\end{array}$ & $\begin{array}{l}0.20- \\
0.49\end{array}$ & $\begin{array}{l}0.50- \\
0.79\end{array}$ & $\begin{array}{l}0.80- \\
1.09\end{array}$ & $\begin{array}{l}1.10- \\
1.49\end{array}$ & $\begin{array}{l}1.50 \\
\text { or } \\
\text { More }\end{array}$ \\
\hline$\left(\eta^{2}\right)$ & $\begin{array}{l}\text { Less } \\
\text { Than } \\
0.010\end{array}$ & $\begin{array}{l}0.010 \\
- \\
0.058\end{array}$ & $\begin{array}{l}0.059 \\
- \\
0.137\end{array}$ & $\begin{array}{l}0.138 \\
- \\
0.231\end{array}$ & $\begin{array}{l}0.232 \\
- \\
0.359\end{array}$ & $\begin{array}{l}0.360 \\
\text { or } \\
\text { More }\end{array}$ \\
\hline
\end{tabular}

As shown in the previous tables, the results refer to that effect size for using scamper strategy is huge. So the hypothesis is accepted. This means that there is a significant effect size for using scamper strategy in developing English generative thinking skills for the students of secondary stage.

\section{7 Discussion of the study:}

The present study investigated the effectiveness of using Scamper strategy on developing English generative thinking skills for the students of secondary stage.

The researcher used the pre-post test to compare the performance of the study group. 
The results of the present study showed that generative thinking skills can be developed through the use of Scamper strategy, so this study proves the effectiveness of scamper strategy on developing English generative thinking skills for the students of secondary stage. The findings of the study were encouraging as they showed that there were statistically differences between the mean scores of the study group on the total generative skills pre-post test; those differences are in favor of post implementation.

The pre-post test results reveal that there is a significant statistical difference between the mean scores of the study group students in the generative thinking skills as a whole in the pre-post test. Therefore, it can be claimed that generative thinking skills proved to be statistically and educationally significant on developing the study group's generative thinking fluency, flexibility and originality skills. The students' scores on the pre test were unsatisfactory. Before implementing the strategy, they had not got any training in the previously specified skills. Through the pre testing, most of their responses were irrelevant; they hardly produce ideas in answer to the questions. Most of the participants had difficulty in how to generate appropriate ideas in answer to the questions. On the contrary, the steps of Scamper strategy given to the study group during applying the experiment have helped the students of the study group activate and develop their generative thinking fluency, 
flexibility and originality skills. Such development might be due to the nature of Scamper strategy that had various options and made the lesson as a game. During the experimentation, the researcher noticed that the students' generative skills were improved. They generated so many ideas that were varied, unique and unusual.

The five hypotheses of the study were accepted. By these results, the researcher became aware that Scamper strategy was effective in developing first year secondary stage students' English generative thinking skills. The adapted units based on Scamper strategy promoted students' generative thinking skills. The findings revealed that they are in accordance with those of Fahmy (2017), Idek (2016), Nassef, (2015), Radwan (2015), concerning the effectiveness of Scamper strategy in developing EFL skills and it is a good idea for generating ideas. The findings were also accorded to those of Khawaldeh (2016), Rahim and Nahid (2013), and Al-Badreen (2013), reporting that Scamper develops thinking skills in general. In addition, the findings are in line with those of Ozyaprak (2016), Islam (2016), Idek (2016), Radwan, (2015), and Nassef (2015) that asserted that Scamper develops EFL thinking skills and thinking skills. -The researcher also finds out that Scamper can be used as an effective strategy to help the first year secondary stage students overcome the difficulties of idea generation. 


\section{Conclusion:}

-The researcher finds out that Scamper strategy is effective on developing English generative thinking skills (fluency skill, flexibility skill and originality skill and their sub-skills).

-This study presents four adapted units according to Scamper strategy to improve English generative thinking skills among the first year secondary stage students.

-This study presents a teacher's guide for the four modified units to help the teachers develop English generative thinking skills for the first year secondary stage students.

-This study helps learners overcome the problems of English generative thinking. Also, it provides teachers with a guide to develop the English generative thinking skills using Scamper strategy, so the researcher can conclude that Scamper strategy should be integrated in teaching with generative thinking skills.

\section{Recommendations:}

1. Students should be provided with syllabuses based on Scamper strategy along different educational stages to generate ideas connected to the different school subjects.

2. Teachers should use Scamper strategy in addition to using other teaching strategies in early educational stages and particularly with higher stages to help them generate ideas. 
3. Teachers should be provided with teaching courses based on Scamper strategy for developing generative thinking skills.

4. Teachers should encourage their students to use the skills of generative thinking though different situations and different educational activities.

5. Teachers should attend workshops and be coached by specialists to increase knowledge and familiarity with Scamper.

\section{Suggestions for further research:}

In the light of the findings of the present study, further research should be done to investigate:

1. The effect of using other strategies (e.g. TRIZ, Mind Mapping, CORT) on developing English generative thinking skills.

2. The effect of using Scamper strategy on developing other English language skills.

3. The effect of using Scamper Strategy on developing English generative thinking skills (speaking) for the students of secondary stage.

4. The effect of using Scamper strategy on developing English generative thinking skills (writing) for the students of the prep stage.

5. The effect of using Scamper strategy on developing English generative thinking skills (speaking) for the students of the prep stage. 


\section{References}

-Al-Badareen, S.K. (2013). The use of a modified strategybased module in developing creative thinking and self-concept of low achievers in Jordan. PhD thesis, Universiti Sains Malaysia.

-Animasahum, R.A (2014). Employing creativity skills in the delivery of academic content: focus on effective teaching and evaluation for sustainable development in the third world nations. Journal of Emerging Trends in Educational Research and Policy Studies (JETERAPS ), 5(7):104-110. University of Ibadan, Ibadan.

-Chesters, S. D. (2012). The Socratic classroom: Reflective thinking through collaborative inquiry. Rotterdam, Boston and Taipei: Sense Publishers.

-Chulvi, V., Cruz, M., Mulet, E. \& Zambrano, J. (2013). Influence of the type of idea- generation method on the creativity of solutions. Springer Link 24(1), 33-41.

-Conklin, W. (2012). Strategies for developing Higher-Order thinking skills. Shell Education.

-Cox, D. (2012). Creative thinking for dummies. Chichester, West Sussex: John Wiley \& Sons, Ltd.

-Eberle, B. (1996). Scamper: Games for imagination development. United States: Prufrock Press Inc. 
-Eberle, B. (2008). Scamper: Creative games and activities for imagination development $\left(2^{\text {nd }}\right.$ ed). United States: Prufrock Press Inc.

-Fahmy, G. A. (2017). Using SCAMPER-based activities in teaching story to Enhance EFL primary stage pupils' speaking skills. JRCIET, 3(4).

-Glenn, R. E. (1997). Scamper for student creativity. Education Digest; Ann Arbor, 62(6) 67-86.

-Gowda, N. S. (2015). Learning and learner: Insights into the processes of learning( $2^{\text {nd }}$ ed). Delhi: PHI Learning Pvt. Ltd.

- Grabowski, B. (2004). Generative learning contributions to the design of instruction and learning. In D. Jonassen (Ed), Handbook of research on educational communications (pp. 719-739). The USA: Communications and Technology. -Haridy, M. (2017). Statistically effectiveness: Simple gain ratio and temporary gain ratio. Association of Arab Educators, (20), 367-379.

-Herring, S. R., Jones, B. R. \& Bailey, B. P. (2009). Idea generation techniques among creative professionals. Proceedings of the $42^{\text {nd }}$ Hawaii International Conference on System Sciences. University of Illinois. UrbanaChampaign.Doi:10.1109/HICSS.2009.241.Source:

IEEE Xplore. 
-Hudson, k. (2010). Speed thinking: How to thrive in a time poor world. Australia:ALLEN \& UNWIN.

-Idek, M. (2016). Measuring the application of SCAMPER technique in facilitating critical and creative thinking in composing short stories and poems. Malaysian Journal of Higher Order Thinking Skills in Education.

-Islam, O. F. (2016). Using the Scamper technique in Ict course to enhance creative problem solving skills. The Turkish Online Journal of Educational Technology.

-Ismail, M. R. (2011). Generative learning strategy. Scientific Education.

-Johnson, A., Morrison, G. \& Ross, S. (1992). Using elaboration strategies training in computer-based instruction to promote generative learning. Contemporary Educational Psychology, 17(2), 125-135.

-Kish, M. H. (2008). Generative learning model to teach adult learners digital imaginery. In L. Tomei (Ed), Encycolopedia of Information Technology Curriculum Integration (pp. 357-358). New York, USA: Information Science Reference.

-Khawaldeh, H. M. (2016). The different impact of SCAMPER and CoRT programs on creative thinking among gifted and talented students. Asian Journal of Multidisciplinary Studies, 4(12), 1-14. 
-Kramer, M. W., Kuo, C. L. \& Dailey, J. C. (1997). The impact of brainstorming Technique on subsequent group processes beyond generating ideas. Research Article.

-Lin, C. L., Hong, J. C., Hwang, M. Y., \& Lin, Y. L. (2006). A study of applicability of idea generation techniques. The Proceedings of the XVII ISPIM Conference, Athens, Greece, 11-14 June 2006 ISBN 952-214-213-1.

-Michalko, M. (2006). Thinker toys: $A$ handbook for creative thinking techniques. Berkeley, CV: Ten Speed Press.

-Osborne, R. \& Freyberg, P. (1985). Learning in science. The implications of children's science. Heinemann Educational Books.

-Ozyaprak, M. (2016). The effectiveness of SCAMPER technique on creative thinking skills. Journal for the Education of Gifted Young Scientists. 4(1), 31-40.

-Radwan, F. E. (2015). Effectiveness of a SCAMPER Program in developing creative writing skills in the English language for the female talented students in the secondary stage (Doctoral dissertation). Al-Arish Faculty of Education. Suez Canal University: Al-Arish, Egypt.

-Rahim, B. G. \& Nahid, K. (2013). The effects of idea seeking (SCAMPER) on creativity of female technical-engineering students in Tabriz University. Innovation \& Creativity in Human Sciences. 3(2), 151-167. 
-Rietzschel, E. F., Nijstad, B. A. \& Stroebe, W. (2006). Productivity is not enough: A comparison of interactive and nominal brainstorming groups on idea generation and selection. Journal of Experimental Social Psychology,42(2), 244-251. -Sullivan, B. (2016). The Design Studio Method: creative problem solving with UX sketching. New York and London: Focal Press.

-Serrat, O. (2009). Knowledge Solutions: tools, methods, and approaches to drive development forward and enhance its effects. Mandaluyong City, Philippines: Asian Development Bank.

-Wittrock, M. C. (1989). Generative processes on comprehension. Educational Psychologist, 24(4), 345-376. 